\title{
Safety Evaluations of the Cry1Ia1 Protein Found in the Transgenic Potato 'SpuntaG2'
}

\author{
Hector Quemada \\ Institute of International Agriculture, 319 Agriculture Hall, Michigan State University, East Lansing, \\ MI 48824; and Donald Danforth Plant Science Center, St. Louis, MO 63132
}

\author{
Kelly Zarka \\ Department of Crop and Soil Sciences, A499B Plant and Soil Science Building, Michigan State \\ University, East Lansing, MI 48824
}

\author{
Walter Pett \\ Department of Entomology, 444 Natural Science Building, Michigan State University, East Lansing, \\ MI 48824
}

\author{
Gurling Bothma \\ Agricultural Research Council, Vegetable and Ornamental Plant Institute, Private Bag X293, \\ Pretoria, 0001 South Africa
}

Kimberly Felcher

Department of Crop and Soil Sciences, A499B Plant and Soil Science Building, Michigan State

University, East Lansing, MI 48824

Hope Mirendil
Department of Biology, Calvin College, Grand Rapids, MI

Muffy Koch

Independent consultant, 4502 Donnelly Drive, RR\#4, Merrickville, ON, Canada, K0G 1N0

\author{
Johan Brink \\ Institute of International Agriculture, 319 Agriculture Hall, Michigan State University, East Lansing, \\ MI 48824

\section{David Douches ${ }^{1}$ \\ Department of Crop and Soil Sciences, A499B Plant and Soil Science Building, Michigan State University, East Lansing, MI 48824}

\begin{abstract}
AdDitional INDEX wORDs. tuber moth, Phthorimaea operculella, Bt, NPTII, insect resistance
Abstract. The transgenic potato 'SpuntaG2' (Solanum tuberosum), which is resistant to potato tuber moth (Phthorimaea operculella), was subjected to protein safety evaluations including protein equivalency tests for the Cry1Ia1 protein from 'SpuntaG2' and bacterially produced Cry1Ia1, toxicity and allergenicity evaluations of Cry1Ia1 protein, and compositional equivalency of 'SpuntaG2' compared with non-transgenic 'Spunta'. Western blot analysis and biological activity assays showed molecular and functional equivalency between 'SpuntaG2'-derived Cry1Ia1 protein and bacteria-derived Cry1Ia1 protein. Comparison of the Cry1Ia1 amino acid sequence to known amino acid sequences revealed no significant homology to known toxins or known allergens. Acute toxicity studies using rodents were used to calculate an acceptable daily intake (ADI) value of $20 \mathrm{mg} \cdot \mathrm{kg}^{-1}$ body weight per day. The ADI value was then used to calculate a margin of exposure (MOE) of 2,222,222, which is more than 22,000 times greater than the commonly used target MOE of 100. Digestibility and thermostability assays determined that Cry 1 Ia 1 was fully digested within $30 \mathrm{~s}$ of exposure to pepsin and inactive after 3 to 4 minutes at $100{ }^{\circ} \mathrm{C}$, indicating that it would not be a potential allergen. Compositional analyses revealed no difference between 'SpuntaG2' and non-transgenic 'Spunta'. These results strongly indicate that the Cry1Ia protein and the transgenic potato 'SpuntaG2' is not a human health risk.
\end{abstract}

'SpuntaG2', a transgenic potato resistant to potato tuber moth, has been previously described by Douches et al. (2002). 'SpuntaG2' contains two foreign genes: crylla1, a gene derived from the soil-borne bacterium Bacillus thuringiensis and nptII,

Received for publication 19 Jan. 2010. Accepted for publication 15 Apr. 2010. ${ }^{1}$ Corresponding author. E-mail: douchesd@msu.edu. a gene derived from the bacterium Escherichia coli (Beck et al., 1982). CrylIa1 is a protein that is toxic to potato tuber moth, and acts by binding to specific receptors on the membranes of epithelial cells in the target insect's midgut. Binding to the receptors causes an ion channel to form between the cell cytoplasm and the external environment, resulting in the loss of osmotic regulation and insect death (Gill et al., 1992). 
Another foreign gene that is expressed in 'SpuntaG2' is nptII (neomycin phosphotransferase), which is a protein that confers resistance to the antibiotic kanamycin and is used as a selectable marker during the transformation process. The 29-kDa neomycin phosphotransferase enzyme inactivates aminoglycoside antibiotics by transferring the $\gamma$-phosphate from ATP to the respective antibiotic. A complete characterization of the 'SpuntaG2' transgenic event has been conducted (Zarka et al., 2010) and they showed that there is a single copy of each gene with no interruption of endogenous genes during the transformation process. That article is the first one in a three-article series and contains a complete research rationale.

We report here, in the second article of the series, on the protein safety evaluations conducted on the foreign proteins in 'SpuntaG2' plants. The Cry1Ia1 protein analysis includes protein equivalency tests for the Cry1Ia1 protein from 'SpuntaG2' and bacterially produced Cry1Ia1, toxicity and allergenicity evaluations of Cry1Ia1 protein, compositional equivalency of 'SpuntaG2' compared with non-transgenic 'Spunta', molecular and functional equivalency between 'SpuntaG2'-derived Cry1Ia1 protein and bacterial-derived CrylIal protein, and homology analysis to known toxins or known allergens. These experiments were conducted in accordance with the guidelines set forth by Codex Alimentarius (2003), which represent the international scientific standard on the process and data requirements for assessment of food safety relating to genetically modified plants. Particular attention was given to the requirements pertaining to food and feed safety, as contained in sections 5.1 and 5.2 of the guidelines for the use of genetically modified organisms. The other foreign protein in 'SpuntaG2' is the NPTII protein and has been previously evaluated and proven safe by the European Food Safety Authority (2007) and Fuchs et al. (1993b). The amount of NPTII expression in 'SpuntaG2' was evaluated and compared with other reported levels of expression.

\section{Materials and Methods}

Production of purified Cry1Ia1 protein. The expression vector system pET28b (Novagen, Madison, WI) was used for cloning and expression of the cryllal gene. pET28b was digested with the BamHI restriction enzyme and the linearized plasmid was then ligated to a BamHI fragment of the cryllal gene. The resulting plasmid was sequenced and named pSPUD56. It was then transformed into the $E$. coli strain BL21(DE3) (Novagen), a general-purpose expression host. The protein was expressed with an N-terminal histidine tag, which enabled it to be purified with Ni-NTA agarose (Qiagen, Valencia, CA).

Ten liters of E. coli BL21(DE3) pSPUD56 were produced at the Protein Expression Laboratory of Michigan State University (East Lansing) according to the following protocol: a 250-mL overnight culture of BL21(DE3) pSPUD56 was used to inoculate a $10-\mathrm{L}$ vessel containing HM medium. The HM medium was prepared by dissolving $9 \mathrm{~g}$ of $\mathrm{KH}_{2} \mathrm{PO}_{4}, 6 \mathrm{~g}$ of $\mathrm{K}_{2} \mathrm{HPO}_{4}, 4 \mathrm{~g}$ of $\mathrm{Na}_{2} \mathrm{HPO}_{4}$, and $3 \mathrm{~g}$ of $\left(\mathrm{NH}_{4}\right)_{2} \mathrm{HPO}_{4}$ in $940 \mathrm{~mL}$ of distilled $\mathrm{H}_{2} \mathrm{O}$ and autoclaving this for $30 \mathrm{~min}$ at $121{ }^{\circ} \mathrm{C}$ on liquid cycle. After cooling the solution to $<40{ }^{\circ} \mathrm{C}, 40 \mathrm{~mL}$ of autoclaved $50 \%$ glucose, $15 \mathrm{~mL}$ of autoclaved $1 \mathrm{M} \mathrm{MgSO}_{4}$, and $5 \mathrm{~mL}$ of sterile trace element solution were added. The trace element solution consisted of $10 \mathrm{~g}$ of $\mathrm{FeSO}_{4}, 2.5 \mathrm{~g}$ of $\mathrm{ZnSO}_{4} \cdot 7 \mathrm{H}_{2} \mathrm{O}, 1 \mathrm{~g}$ of $\mathrm{CuSO}_{4} \cdot 5 \mathrm{H}_{2} \mathrm{O}, 1 \mathrm{~g}$ of $\mathrm{MnSO}_{4} \cdot 5 \mathrm{H}_{2} \mathrm{O}, 1 \mathrm{~g}$ of $\mathrm{CoCl}_{12} \cdot 6 \mathrm{H}_{2} \mathrm{O}, 1 \mathrm{~g}$ of $\mathrm{Na}_{2} \mathrm{MoO}_{4} \cdot 2 \mathrm{H}_{2} \mathrm{O}, 5 \mathrm{~g}$ of $\mathrm{CaCl}_{12} \cdot 2 \mathrm{H}_{2} \mathrm{O}$, and $0.2 \mathrm{~g}$ of $\mathrm{Na}_{2} \mathrm{~B}_{4} \mathrm{O}_{7} \cdot 10 \mathrm{H}_{2} \mathrm{O}$ dissolved in $1 \mathrm{~L}$ of $5 \mathrm{M} \mathrm{HCl}$. The $10-\mathrm{L}$ vessel containing the HM medium and BL21(DE3)pSPUD56 culture was agitated at $500 \mathrm{rpm}$ with an air flow rate of $1 \mathrm{~L} \cdot \mathrm{min}^{-1}$ while the $\mathrm{pH}$ was controlled by adding ammonia. After $12 \mathrm{~h}$ of culture, IPTG was added to a final concentration of $0.5 \mathrm{~mm}$ to induce production of the Cry1Ia1 protein. The dissolved oxygen was maintained below $10 \%(\mathrm{w} / \mathrm{v})$ by adding $2.8 \mathrm{M}$ glucose as needed. After $6 \mathrm{~h}$ of induction, the cells were harvested by centrifugation and the wet pellet was stored at $-80{ }^{\circ} \mathrm{C}$ until purification.

The $E$. coli pellet was taken from $-80{ }^{\circ} \mathrm{C}$ and resuspended in $\mathrm{PN}$ buffer (50 $\mathrm{mm} \mathrm{NaH}_{2} \mathrm{PO}_{4}$ and $0.3 \mathrm{M} \mathrm{NaCl}, \mathrm{pH} 7.8$ ) containing $1 \%$ Triton X-100 (Bio-Rad, Hercules, CA) and 1 $\mathrm{mg} \cdot \mathrm{mL}^{-1}$ lysozyme in a centrifuge tube. The cell suspension was prepared for and purified with Ni-NTA agarose (Qiagen) according to the manufacturer's instructions. The protein was eluted by adding PN buffer containing $0.5 \%$ Triton X-100 and $0.3 \mathrm{M}$ imidazole. The eluate (containing the purified protein) was collected. The protein solution was then concentrated and simultaneously changed to PEN buffer $\left[50 \mathrm{~mm} \mathrm{NaH}_{2} \mathrm{PO}_{4}\right.$, $0.3 \mathrm{M} \mathrm{NaCl}, 0.5 \mathrm{~mm}$ EDTA, pH 7.8, Protease Inhibitor (Roche Applied Science, Indianapolis), and 10\% glycerol], using centrifugational filter devices (Amicon Ultra-15; Millipore, Bedford, MA). The concentration of protein samples was determined by using a commercially available Bradford Reagent (Bio-Rad) according to manufacturer's instructions. Purified protein preparations were stored at $-80^{\circ} \mathrm{C}$.

The purified protein preparation from the previous step was thawed and concentrated further to $160 \mathrm{mg} \cdot \mathrm{mL}^{-1}$. A sample was diluted and separated by electrophoresis on a 10\% Tris Glycine SDS-PAGE (Bio-Rad) according to Laemmli (1970). After electrophoresis, the gel was stained with SimplyBlue ${ }^{T M}$ SafeStain (Invitrogen, Carlsbad, CA) according to the manufacturer's instructions to confirm the size and purity of the sample. Based on the intensity of the Cry1Ial band, the preparation was judged to be $>90 \%$ pure.

Equivalency of in vitro Cry1Ia1 protein from $E$. Coli and Cry1IA1 Protein from 'SpuntaG2'. Non-transgenic 'Spunta' and 'SpuntaG2' proteins were compared by western blot analysis with $E$. coli-derived Cry1Ia1 protein previously described by $\mathrm{Li}$ et al. (1999). The biological activities of CrylIal protein purified from $E$. coli and CrylIa1 protein contained in sap from 'SpuntaG2' were also compared. While the target insect for 'SpuntaG2' is the potato tuber moth, there currently is no known artificial diet capable of maintaining this insect during the larval stages. However, Cry1Ia1 is also toxic to the tobacco hornworm (Manduca sexta), an insect for which eggs and an artificial diet have been developed and are commercially available. Therefore, the tobacco hornworm was used for this study. The eggs were purchased from the North Carolina State University Entomology Insectary (Raleigh). Once the first instar larvae emerged, the insects were placed in 24 -well plates (Cellbind; Corning, Corning, NY) containing $1 \mathrm{~mL} /$ well commercially prepared tobacco hornworm diet (Carolina Biological Supply, Burlington, NC) and one newly hatched hornworm per well. Purified E. coli Cryllal was mixed into the wells at concentrations of $0.1,0.5,1.0,1.5$, and $2.5 \mu \mathrm{g} \cdot \mathrm{mL}^{-1}$. As a control, $100 \mu \mathrm{L}$ of ddH2O was mixed with the diet $(0 \mu \mathrm{g}$ of Cry1Ial protein). Twenty-four replicate wells were prepared for each protein concentration. The larvae were added and the plates were placed at room temperature for $72 \mathrm{~h}$. The surviving larvae were recorded. 
To determine the activity of the Cry1Ia1 protein in 'SpuntaG2', leaf tissue was extracted from the non-transgenic 'Spunta' control or from 'SpuntaG2'. Using a mortar and pestle, leaf tissue samples were ground and the sap was removed by pipetting. This sap sample was centrifuged at $2000 g_{n}$ for 5 s to pellet any large debris. The sap was transferred to a new tube. The sap was weighed and it was determined that the sap represented $0.001 \mathrm{~g}$ of fresh wet leaf tissue weight per microliter. The liquid sap was then mixed into the commercial diet in the wells $(10 \mu \mathrm{L}=0.01 \mathrm{~g}$ tissue, $25 \mu \mathrm{L}=0.025 \mathrm{~g}$ tissue, $50 \mu \mathrm{L}=0.05 \mathrm{~g}$ tissue, and $100 \mu \mathrm{L}=$ $0.1 \mathrm{~g}$ tissue). The larvae were added and the plates were placed at room temperature for $72 \mathrm{~h}$. The surviving larvae were then recorded.

Toxicology. Homology of Cry1Ia1 protein to known toxins was assessed using the approach described by Rice et al. (2008). The amino acid sequence of the CrylIal protein was used to query the database using the algorithm, Basic Local Alignment Search Tool Protein (BLASTP) (Altschul et al., 1997). The BLASTP algorithm was implemented via the National Center for Biotechnology Information (NCBI, 2010). The default parameters were used. This implementation of the BLASTP algorithm searches the protein- $n r$ public database of protein sequences. The delimiting phrase "toxin OR toxic NOT insecticidal NOT pesticidal NOT delta endotoxin" was used. This delimiter was used because an initial search using just the phrase "toxin OR toxic" returned only Cry proteins, and was therefore not informative.

The acute toxicity of Cry1Ia1 protein was evaluated by MPI Research, Mattawan, MI (MPI Research, Inc., 2008). Purified Cry1Ial protein was used and the study was conducted in compliance with the U.S. Food and Drug Administration (USFDA, 2008). USFDA and international guidelines were followed (International Conference on Harmonisation of Technical Requirements for Registration of Pharmaceuticals for Human Use, 1997; USFDA, 2004). One treatment group of 10 male and 10 female $\mathrm{Crl}: \mathrm{CD} 1{ }^{\circledR}$ (Icr) mice was administered the test article, Cry1IA1 protein, at a dose level of $2000 \mathrm{mg} \cdot \mathrm{kg}^{-1}$ and at a dose volume of $12.5 \mathrm{~mL} \cdot \mathrm{kg}^{-1}$. One additional group of 20 animals (10 males and 10 females) served as the control and received the vehicle, control buffer, at a dose volume of $12.5 \mathrm{~mL} \cdot \mathrm{kg}^{-1}$. The test article or vehicle was administered via oral gavage, once on Day 1. Observations for mortality, morbidity, injury, and the availability of food and water were conducted twice daily for all animals. Clinical observations were conducted once on day 1 ( $\approx 1 \mathrm{~h}$ post dose), day 7 , and day 14. Body weights and food consumption were measured and recorded weekly. At study termination, necropsy examinations were performed, organ weights were recorded, and selected tissues were preserved.

Allergenicity. The search for sequence similarity between the CrylIal protein and known allergens was conducted by comparing the amino acid sequence of CrylIal with the database of known allergens, AllergenOnline (University of Nebraska-Lincoln, 2010). Sequence similarity was done using the FASTA3 algorithm (Pearson, 2000), accessed through the AllergenOnline website. The website conducts two types of sequence searches: 1) an overall FASTA search of the AllergenOnline database, and 2) an 80-amino acid sliding window search in which sequential 80-amino acid segments of the protein are generated and each is used to query the AllergenOnline database. In these sequence searches, Codex Alimentarius (2003) considers allergenicity to be a possibility if there is $35 \%$ (or more) identity between the protein in question and a known allergen in a segment of at least 80 amino acids.

In addition to sequence analyses, Codex Alimentarius (2003) also recommends a test to determine the ability of pepsin to digest the protein in question. Therefore, the digestibility of the Cry1 Ia1 protein was investigated in an in vitro digestibility assay according to the procedure followed by $\mathrm{Fu}$ et al. (2002). To initiate a time course experiment, $665 \mu \mathrm{L}$ of SGF solution was incubated at $37^{\circ} \mathrm{C}$ for $2 \mathrm{~min}$, and then $35 \mu \mathrm{L}$ of the purified Cry1 Ia1 protein at $5 \mathrm{mg} \cdot \mathrm{mL}^{-1}$ was added; $100 \mu \mathrm{L}$ of sample was removed and added to a separate tube containing $35 \mu \mathrm{L}$ of 200 $\mathrm{mm} \mathrm{NaHCO}_{3}$ (pH 11.0) and $50 \mu \mathrm{L} 3 \times$ Laemmli sample buffer. The neutralized samples were analyzed by SDS polyacrylamide resolving gel run according to Laemmli (1970) along with a 0 time point, which consisted of $0.7 \mu \mathrm{g}$ of Cry1Ia1 protein that was added to already neutralized SGF. Results were visualized by staining the gel with Coomassie Blue.

Another criterion for assessing the allergenic potential of a protein is its thermostability as measured by activity (Delaney et al., 2008). The stability of the Cry1Ial protein after being exposed to heat was studied using tobacco hornworm as a test insect due to the availability of an artificial diet capable of maintaining this insect during the larval stages. The tobacco hornworm eggs were purchased from the North Carolina State University Entomology Insectary (Raleigh). Cellbind 24-well plates were used for this study with two wells per dose of Cry1Ia1 per time point, and only one well per time point, up to $3 \mathrm{~min}$, was used for the control. Purified Cry1Ial protein was placed in a hot block set at $100^{\circ} \mathrm{C}$. At 0 , $1,2,3,4$, and $5 \mathrm{~min}$ a sample $\left(10\right.$ or $100 \mu \mathrm{g} \cdot \mathrm{mL}^{-1}$ in $100 \mu \mathrm{L}$ of $\mathrm{ddH}_{2} \mathrm{O}$ ) was removed and mixed into the diet (Carolina Biological Supply). As a control, $100 \mu \mathrm{L} \mathrm{ddH}_{2} \mathrm{O}$ was mixed with the diet ( $0 \mu \mathrm{g}$ of Cry1Ia1 protein). Two newly hatched first instar larvae were added to each well and the plates were placed at room temperature for $72 \mathrm{~h}$. The surviving larvae were then recorded.

Compositional Analysis of 'SpuntaG2'. The nutritional composition of 'SpuntaG2' was analyzed in comparison with non-transgenic 'Spunta'. This analysis, in conjunction with a comparison of agronomic characteristics, are the primary analyses recommended by Codex Alimentarius (2003) for the assessment of unintended effects resulting from the transformation process. The components analyzed were based on those specified by the Organization for Economic Co-operation and Development (OECD, 2002; Rogan et al., 2000). Potatoes were sampled in South Africa from four replicate plots of 'SpuntaG2' and 'Spunta' at two locations (Kokstad and Petrus Steyn) and from three replicate plots at Roodeplaat. Freshly harvested tubers from each plot were placed in individual piles. 'Spunta' and 'SpuntaG2' tubers $(\approx 3 \mathrm{~kg})$ were randomly removed from each pile and placed in bags. About $1 \mathrm{~kg}$ of fresh tubers was removed from the bags and the tubers were washed and diced into cubes about $1 \mathrm{~cm}^{3}$ in size. The diced tuber pieces were placed in plastic bags, frozen at $-20{ }^{\circ} \mathrm{C}$, and sent to and analyzed by Agricultural Research Council-Irene Analytical Services (Pretoria, South Africa), a South African National Accreditation System accredited laboratory. The data were analyzed by two-way analysis of variance, with Buonferroni post-tests, using GraphPad PRISM software (version 5.0 for Mac; GraphPad PRISM Software, San Diego). Nutrients that were not detected were not included in the statistical analysis. 
A rodent feeding study entitled, "Testing the nutritional adequacy of a genetically modified 'Spunta' potato using the rat model," was conducted by the Agricultural Research Council Toxicology (Pretoria, South Africa) as an additional assurance of nutritional adequacy and absence of unintended effects. Before the study described in this article, a pilot study was conducted to determine the nutritional adequacy of various test doses of nontransgenic potato on rats. This study showed no adverse nutritional effect of $30 \%(\mathrm{w} / \mathrm{v})$ potato, the highest dose tested, and therefore this dose was chosen for the main study. Pellets containing $30 \%(\mathrm{w} / \mathrm{v})$ potato meal were made by mixing the freeze-dried 'Spunta' or 'SpuntaG2' potato tubers with the milled standard rodent pellets (Onderstepoort Biological Products, Pretoria, South Africa) and reformulating pellets from the mixture. Standard proximate analysis of the freeze-dried tubers as well as test and control pellets was done to assure nutritional equivalence.

Young Sprague-Dawley rats (female $n=30$, male $n=30$ ), with masses between 49 and $78 \mathrm{~g}$, were obtained from National Health Laboratory Services (Johannesburg, South Africa) and kept in an environmentally controlled small animal facility. During the adaptation period of 1 week, tap water and standard rat pellets were provided ad libitum. The rats were divided randomly into six groups $(\mathrm{n}=10)$ according to the following scheme: control female and male groups: standard pellets only; 'Spunta' female and male groups: pellets containing 30\% (w/v) 'Spunta'; 'SpuntaG2' female and male groups: pellets containing 30\% (w/v) 'SpuntaG2'.

During the main trial ( $90 \mathrm{~d}$ ) rats were kept in single cages facing one another and tap water and feed were provided ad libitum. The individual body masses as well as the feed intake were recorded twice weekly to compute and compare some of the performance parameters (body mass gain, food intake, final body mass, and feed efficiency). Temperature was maintained at $23{ }^{\circ} \mathrm{C}$ to $24{ }^{\circ} \mathrm{C}$, relative humidity varied between $43 \%$ and $65 \%$, and lighting was controlled on a 12/12-h light/dark cycle (lights on at $0600 \mathrm{HR}$; lights off at $1800 \mathrm{HR}$ ). The experiment was ended by euthanizing the rats (overdose of pentobarbitone sodium $200 \mathrm{mg} \cdot \mathrm{mL}^{-1}$ at a dose of $1-2$ $\mathrm{mL} \cdot \mathrm{kg}^{-1}$ intraperitoneally), immediately followed by collecting blood from the heart $(1.5 \mathrm{~mL}$ with a $24 \mathrm{G}$ needle) and removing the liver, heart, kidney, spleen, lungs, and ovaries or testes for weighing. The blood was centrifuged (at $1200 g_{n}$ for $10 \mathrm{~min}$ ) and the serum was collected and submitted for clinical chemistry and hematology on whole blood.

DETERMINATION OF NPTII EXPRESSION IN 'SPUNTAG2'. A commercial NPTII ELISA kit (catalog no. PSP 73000; Agdia, Elkhart, IN) was used to determine the level of NPTII protein present in 'SpuntaG2'. Freeze-dried leaves were ground in sample buffer (PEB1, supplied by the manufacturer) at a concentration of $10 \mathrm{mg} \cdot \mathrm{mL}^{-1}$ and were then diluted to $2.5 \mathrm{mg} \cdot \mathrm{mL}^{-1}$ CrylIal protein. dry weight. This dilution was determined in previous experiments to provide readings in the linear range of response for the assay. Samples were loaded onto pre-coated ELISA plates (100 $\mu \mathrm{L} /$ well) along with standards comprised of 2 -fold serial dilutions of positive controls, as well as negative control samples on each plate. The optical density of each well was read with a microplate reader (model 50; Varian Cary, Palo Alto, CA). Four replicate experiments, done on different dates, were conducted. Concentrations of NPTII protein were based upon standards run on the same plate, at the same time.

\section{Results}

Western blot results (Fig. 1) show that the rabbit polyclonal Cryllal antibody used in this experiment reacts with the CrylIal and is equal in size to the CrylIal protein purified from $E$. coli. The antibody reacts non-specifically with three proteins found in the 'SpuntaG2' extracts; however, it also reacts in the non-transformed extracts.

M. sexta larvae were sensitive to purified Cry1Ia1 protein with a dose of $2.5 \mu \mathrm{g} \cdot \mathrm{mL}^{-1}$ producing $100 \%$ mortality (Table 1 ). 'SpuntaG2' leaf extracts showed a similar effect on M. sexta larvae with even the lowest dose tested resulting in $50 \%$ mortality. In contrast, the number of surviving insects in the 'Spunta' non-transgenic control extract of $0.1 \mathrm{~g} /$ well was equal to the number of surviving insects in the $0 \mu \mathrm{g} \cdot \mathrm{mL}^{-1}$ Cry1Ia1 control (Table 1).

To assess whether the Cry1Ia1 protein has homology to any known toxin, the amino acid sequence of the Cry1Ial protein was used to query the database using the algorithm, BLASTP (Altschul et al., 1997). Although we attempted to remove Cry proteins from the search results to focus on proteins that had known human or animal toxicity, most of the results of this search were still Cry insecticidal proteins. Those that were not Cry proteins had very low similarity to Cry1Ial (E score $>2$ ), and are therefore unlikely to be related in function to Cry1Ia1. Furthermore, for proteins to share the same function, a sequence

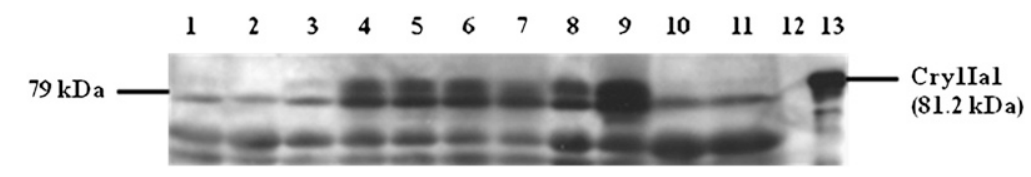

Fig. 1. Equivalence of apparent molecular weight and antigenic re-activities of Escherichia coli Cry1Ia1 and plant extract from transgenic potato lines expressing the protein Cry1 Ia1 ( $\mathrm{Li}$ et al., 1999). Lane $1=$ non-transgenic potato 'Spunta'; lane 2 = non-transgenic potato '80-1'; lanes 3-11 = transgenic Cry1 Ia1 'Spunta' lines 6a1, 6a2, 6a3, 6a4, and 6a5,'SpuntaG2, 'SpuntaG3,' $80-1.9$, and 80-1.25, respectively; lane $12=$ blank; lane $13=$ E. coli

Table 1. Toxicity of purified Escherichia coli Cry1Ia1 protein and potato leaf extracts from 'Spunta' and 'SpuntaG2' on Meduca sexta larvae.

\begin{tabular}{lccc}
\hline $\begin{array}{l}\text { Cry1Ia1 } \\
\left(\mu \mathrm{g} \cdot \mathrm{mL}^{-1}=\mu \mathrm{g} / \mathrm{well}\right)\end{array}$ & $\begin{array}{c}\text { Larvae living } \\
\text { after } 72 \mathrm{~h}(\text { no. })^{\mathrm{z}}\end{array}$ & $\begin{array}{c}\text { 'Spunta' and 'SpuntaG2' } \\
\text { (g of leaf extract) }\end{array}$ & $\begin{array}{c}\text { Larvae living } \\
\text { after } 72 \mathrm{~h}(\text { no. })^{\mathrm{z}}\end{array}$ \\
\hline 0.0 & 19 & 'Spunta' 0.10 & 19 \\
0.1 & 7 & 'Spunta' 0.01 & 20 \\
0.5 & 5 & 'SpuntaG2' 0.10 & 2 \\
1.0 & 2 & 'SpuntaG2' 0.05 & 0 \\
1.5 & 3 & 'SpuntaG2' 0.02 & 6 \\
2.5 & 0 & 'SpuntaG2' 0.01 & 10 \\
\hline
\end{tabular}

${ }^{\mathrm{z}}$ Twenty-four first instar larvae were tested per protein concentration. 
identity of at least $40 \%$ is required (Wilson et al., 2000). None of the non-Cry1 proteins shared that level of sequence identity, and the matches returned by BLASTP were for only portions of the proteins in the database.

The acute toxicity test established a no adverse effect level (NOAEL) of $2000 \mathrm{mg} \cdot \mathrm{kg}^{-1}$ body weight per day, from which an ADI of $20 \mathrm{mg} \cdot \mathrm{kg}^{-1}$ body weight per day was calculated (Benford, 2000). Using the expression levels of CrylIa1 in 'SpuntaG2' tubers $\left[0.12 \mu \mathrm{g} \cdot \mathrm{g}^{-1}\right.$ fresh weight (Zarka et al., 2010)], the expected dose of Crylla1 consumed by the South African population can be estimated. The South African Medical Research Council (2002) estimates average adult consumption of potatoes at $7.9 \mathrm{~g} \cdot \mathrm{kg}^{-1}$ body weight per day. Therefore, the estimated daily intake (EDI) of Cry1Ial protein, assuming $100 \%$ of the potatoes consumed in South Africa would be 'SpuntaG2', is $0.00000012 \mathrm{~g}$ Cry1Ia1 protein per gram of fresh tuber weight $\times 7.9=0.0000009 \mathrm{~g} \cdot \mathrm{kg}^{-1}$ body weight (i.e., $0.0009 \mathrm{mg} \cdot \mathrm{kg}^{-1}$ ) per day. This dose is 22,000 times less than the ADI ( $20 \mathrm{mg} \cdot \mathrm{kg}^{-1}$ body weight per day). In other terms, the margin of exposure is $2000 / 0.0009=2,222,222$, which is more than 22,000 times greater than the commonly used target MOE of 100.

The sequence comparison of the CrylIa1 protein to known allergens revealed that no sequence similarity exists between Cry1Ia1 and known allergens. In digestibility assays, Cry1Ia1 protein digested within $30 \mathrm{~s}$ in simulated gastric fluid (Fig. 2). The controls with Cry1Ia1 alone (lanes 9 and 10) demonstrate that the protein is specifically degraded by pepsin. The speed of digestion is consistent with other non-allergenic proteins and in particular other Cry proteins that have obtained regulatory approval in several countries worldwide.

One other criterion for assessing the allergenic potential of a protein is its thermostability as measured by activity (Delaney et al., 2008). Therefore, the stability of the Cry1Ia1 protein after being exposed to heat was studied using tobacco hornworm larvae. The number of surviving hornworm larvae in each test well is shown in Table 2. Survival of tobacco hornworms fed CrylIa1 was at $50 \%$ of the controls by $2 \mathrm{~min}$, and at the same level as the controls at $3 \mathrm{~min}$. These results indicate that the Crylla1 protein is inactivated by heating to $100^{\circ} \mathrm{C}$ for 3 to $4 \mathrm{~min}$.

The nutritional composition of 'SpuntaG2' was analyzed in comparison with non-transgenic 'Spunta'. This analysis is one of the primary analyses recommended by Codex Alimentarius (2003) for the assessment of unintended effects resulting from the transformation process. The components analyzed were based on those specified by the OECD (2002) and by Rogan et al. (2000). None of the levels of the nutritional and quality parameters and vitamin, mineral, and amino acid composition of 'SpuntaG2' and 'Spunta' potato tubers differed to a statistically significant degree, with the exception of lysine at only one location, Kokstad (Table 3). Lysine levels of 'SpuntaG2' and 'Spunta' were not significantly different at either of the other two testing locations. The lysine level of 'SpuntaG2' was lower than 'Spunta' at Kokstad, and was slightly lower than the reported range of lysine (77-171 mg/100 g) in Rogan et al. (2000). However, the lysine levels were not significantly different at the other two locations, and all were on the lower end of the reported range. Based on these analyses, we did not reject the null hypothesis that nutrient levels were the same for 'SpuntaG2' and 'Spunta' at all three locations.

In a rodent feeding study, six groups of rats were evaluated where male and female groups were fed on standard pellets,
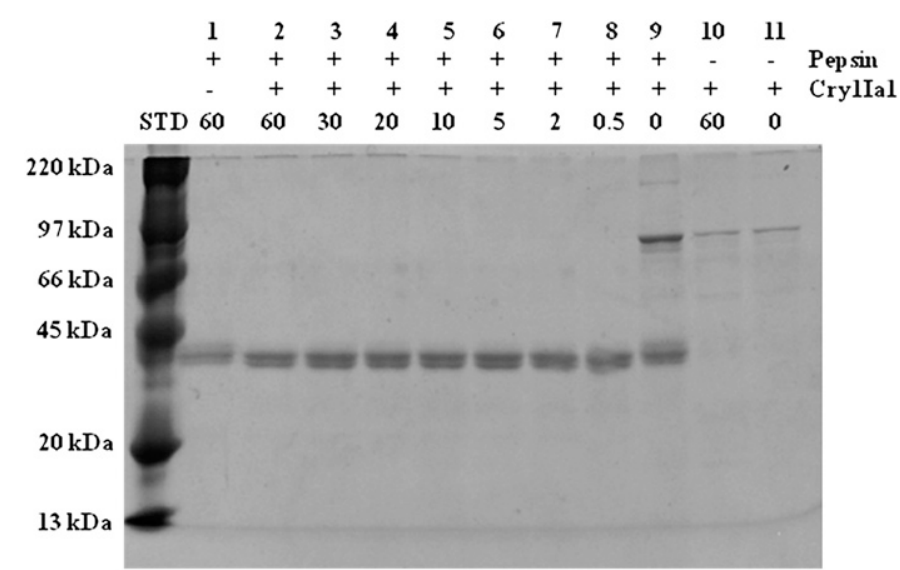

Fig. 2. Polyacrylamide protein electrophoresis time course of digestion of Cry1Ia1 protein in simulated gastric fluid (SGF). STD $=$ molecular weight marker; lane $1=\mathrm{SGF}+$ pepsin only, $60 \mathrm{~min}$; lanes $2-9=\mathrm{SGF}+$ pepsin and Cry1Ia1 for the indicated time (min); lane $10=\mathrm{SGF}+$ Cry1Ia1 only, $60 \mathrm{~min}$; lane $11=\mathrm{SFG}+$ Cry1Ia1 only, 0 min.

Table 2. Bioactivity test on heat treated Escherichia coli-produced CrylIa1 protein using Meduca sexta larvae as the test subject.

\begin{tabular}{|c|c|c|c|c|c|c|c|}
\hline \multirow{3}{*}{$\begin{array}{l}\text { Cry1Ia1 } \\
\left(\mu \mathrm{g} \cdot \mathrm{mL}^{-1}\right)\end{array}$} & \multirow[b]{3}{*}{ Replication } & \multicolumn{6}{|c|}{ Time at $100{ }^{\circ} \mathrm{C}(\mathrm{min})$} \\
\hline & & 0 & 1 & 2 & 3 & 4 & 5 \\
\hline & & \multicolumn{6}{|c|}{ Living hornworms after $72 \mathrm{~h}(\text { no. })^{\mathrm{z}}$} \\
\hline 10 & 1 & 0 & 0 & 1 & 1 & 1 & 2 \\
\hline 10 & 2 & 0 & 0 & 1 & 2 & 2 & 2 \\
\hline 100 & 1 & 0 & 0 & 1 & 2 & 2 & 1 \\
\hline 100 & 2 & 0 & 0 & 1 & 2 & 2 & 2 \\
\hline 0 & 1 & 2 & 2 & 1 & 2 & & \\
\hline
\end{tabular}

${ }^{\mathrm{z}}$ Each well contained $1 \mathrm{~mL}$ of diet, the designated amount of Cry1Ia1 protein, and two newly hatched $M$. sexta larvae.

pellets containing 'Spunta', and pellets containing 'SpuntaG2'. The control and experimental groups had no significant differences for the parameters tested, which included body weight, organ weight, food consumption, clinical sign changes, clinical pathological alterations, clinical chemistry, and hematology (Agricultural Research Council, unpublished results). Therefore, the test animals responded in the same way to the 'SpuntaG2' potato as to its conventional counterpart ('Spunta'), following consumption.

Based on the results of ELISA tests, the concentration of NPTII protein in leaf tissue was $11.34 \mu \mathrm{g} \cdot \mathrm{g}^{-1}$ fresh weight. NPTII protein accounts for $0.07 \%$ of total protein, given that $1.6 \%$ of leaf fresh weight is protein (Stone and Lavrik, 1994). This is consistent with results of studies that have measured $n p t I I$ gene expression in other transgenic potato lines at $2.64 \mu \mathrm{g}$ of NPTII protein per gram fresh weight, or $0.02 \%$ of total protein (Stone and Lavrik, 1994).

\section{Discussion}

In a previous study, 'SpuntaG2', a potato cultivar containing the crylIal gene, was extensively characterized at the molecular level (Zarka et al., 2010). The results indicated that the crylla1 gene in 'SpuntaG2' was unchanged during the transformation process, was stably integrated into the potato 
Table 3. Mean comparison of nutritional and quality parameters and vitamin, mineral, and amino acid composition of 'SpuntaG2' and 'Spunta' potato tubers grown at three South African locations (Kokstad, Petrus Steyn, and Roodeplaat). The least-squares means of 'SpuntaG2' and 'Spunta' were compared within each location.

\begin{tabular}{|c|c|c|c|c|c|c|c|c|c|c|c|c|c|}
\hline \multirow[b]{4}{*}{ Component } & \multirow[b]{4}{*}{ Unit } & \multicolumn{12}{|c|}{ Field location } \\
\hline & & \multicolumn{4}{|c|}{ Kokstad $^{\mathrm{z}}$} & \multicolumn{4}{|c|}{ Petrus Steyn $^{y}$} & \multicolumn{4}{|c|}{ Roodeplaat } \\
\hline & & \multicolumn{2}{|c|}{ SpuntaG2 } & \multicolumn{2}{|c|}{ Spunta } & \multicolumn{2}{|c|}{ SpuntaG2 } & \multicolumn{2}{|c|}{ Spunta } & \multicolumn{2}{|c|}{ SpuntaG2 } & \multicolumn{2}{|c|}{ Spunta } \\
\hline & & Mean & $\mathrm{SE}$ & Mean & $\mathrm{SE}$ & Mean & $\mathrm{SE}$ & Mean & SE & Mean & $\mathrm{SE}$ & Mean & $\mathrm{SE}$ \\
\hline Moisture & $\%$ & 84.4 & 0.34 & 84.2 & 0.34 & 84.9 & 0.34 & 84.3 & 0.34 & 84.8 & 0.39 & 85.4 & 0.39 \\
\hline Ash & $\%$ & 0.878 & 0.028 & 0.845 & 0.028 & 0.845 & 0.028 & 0.760 & 0.028 & 0.887 & 0.032 & 0.843 & 0.032 \\
\hline Protein & $\%$ & 2.08 & 0.05 & 2.12 & 0.05 & 2.29 & 0.05 & 2.26 & 0.05 & 1.82 & 0.06 & 1.63 & 0.06 \\
\hline Fiber (crude) & $\%$ & 0.385 & 0.024 & 0.325 & 0.024 & 0.378 & 0.024 & 0.340 & 0.0 & 0.543 & 0.027 & 0.457 & 0.027 \\
\hline Arginine & $\mathrm{g} / 100 \mathrm{~g}$ & 0.100 & 0.003 & 0.093 & 0.0 & 0.108 & 0.003 & 0.093 & 0.0 & 0.087 & 0.004 & 0.070 & 0.004 \\
\hline Serine & $\mathrm{g} / 100 \mathrm{~g}$ & 0.053 & 0.003 & 0.053 & 0.003 & 0.048 & 0.003 & 0.055 & 0.003 & 0.040 & 0.003 & 0.040 & 0.003 \\
\hline Aspartic acid & $\mathrm{g} / 100 \mathrm{~g}$ & 0.288 & 0.022 & 0.270 & & 0.273 & 0.022 & 0.310 & & 0.260 & 0.026 & 0.207 & 0.026 \\
\hline Glutamic & $\mathrm{g} / 100 \mathrm{~g}$ & 0.318 & 0.016 & 0.305 & 0.016 & 0.328 & 0.016 & 0.358 & 0.0 & 0.267 & 0.018 & 0.207 & 0.018 \\
\hline Glycine & $\mathrm{g} / 100 \mathrm{~g}$ & 0.040 & 0.000 & 0.040 & 0.0 & 0.040 & 0.000 & 0.040 & 0.0 & 0.040 & 0.000 & 0.030 & 0.000 \\
\hline Methionine & $\mathrm{g} / 100 \mathrm{~g}$ & 0.020 & 0.002 & 0.020 & 0.0 & 0.025 & 0.002 & 0.023 & 0.0 & 0.020 & 0.002 & 0.010 & 0.002 \\
\hline Valine & $\mathrm{g} / 100 \mathrm{~g}$ & 0.07 & 0.002 & 0.078 & 0.0 & 0.0 & 0.002 & 0.080 & 0.0 & 0.0 & 0.002 & 0.070 & 0.002 \\
\hline Phenylalanine & $\mathrm{g} / 100 \mathrm{~g}$ & 0.065 & 0.003 & 0.065 & 0.003 & 0.063 & 0.003 & 0.065 & 0.0 & 0.057 & 0.003 & 0.050 & 0.003 \\
\hline Isoleucine & $\mathrm{g} / 100 \mathrm{~g}$ & 0.053 & 0.002 & 0.053 & 0.0 & 0.050 & 0.002 & 0.050 & 0.0 & 0.050 & 0.003 & 0.040 & 0.003 \\
\hline Leucine & $\mathrm{g} / 100 \mathrm{~g}$ & 0.073 & 0.003 & 0.075 & 0.003 & 0.068 & 0.003 & 0.075 & 0.0 & 0.067 & 0.003 & 0.060 & 0.003 \\
\hline Histidine & $\mathrm{g} / 100 \mathrm{~g}$ & 0.053 & 0.004 & 0.043 & 0.0 & 0.050 & 0.004 & 0.050 & 0.0 & 0.043 & 0.004 & 0.037 & 0.004 \\
\hline Lysine & $\mathrm{g} / 100 \mathrm{~g}$ & 0.043 & 0.009 & 0.095 & 0.009 & 0.058 & 0.009 & 0.095 & 0.009 & 0.083 & 0.010 & 0.083 & 0.010 \\
\hline Cysteine & $\mathrm{g} / 100 \mathrm{~g}$ & 0.018 & 0.002 & 0.020 & 0.0 & 0.018 & 0.002 & 0.015 & 0.0 & 0.010 & 0.003 & 0.013 & 0.003 \\
\hline Tryptophan & $\mathrm{g} / 100 \mathrm{~g}$ & 0.020 & 0.001 & 0.020 & 0.001 & 0.018 & 0.001 & 0.020 & 0.001 & 0.020 & 0.002 & 0.013 & 0.002 \\
\hline Vitamin C & $\mathrm{mg} / 100 \mathrm{~g}$ & 5.40 & 0.52 & 4.80 & 0.52 & 6.23 & 0.52 & 5.51 & 0.52 & 4.06 & 0.60 & 2.83 & 0.60 \\
\hline Carbohydrates & $\%$ & 12.6 & 0.34 & 12.7 & 0.34 & 11.9 & 0.34 & 12.6 & 0.34 & 12.4 & 0.40 & 12.0 & 0.40 \\
\hline
\end{tabular}

${ }^{\mathrm{z}}$ Least-squares means for the two potato lines (presented with standard errors) in bold are significantly different compared individually within each location at $\alpha=0.05$.

${ }^{y}$ Sucrose levels were non-detectable for 'Spunta' at the Petrus Steyn location.

genome, did not interrupt or otherwise affect any functional potato genes, and it did not introduce any new open reading frames that would be of concern.

The research reported here was done to assess the safety of expressed foreign proteins in 'SpuntaG2' (Cry1Ia1 and NPTII) and is summarized in Table 4. Western blot analysis and larval feeding studies demonstrated size and functional equivalency between Cry1Ia1 protein from 'SpuntaG2' and E. coli-derived Cry1Ia1. Furthermore, sequence analysis of the protein revealed no significant match with known toxins except for other Cry insecticidal proteins. Acute toxicity tests from our study and ELISA data from Zarka et al. (2010) allowed us to calculate an ADI for the CrylIa1 protein. Assuming a diet including only 'SpuntaG2' potatoes, the EDI for the Cry1Ia1 protein was more than 22,000 times less than the ADI. This highly conservative safety level is assurance that Crylal protein will not have toxic effects on humans who consume the protein in 'SpuntaG2' and other cultivars into which the cryllal gene will be backcrossed.

To assess the allergenicity of Cry1Ia1 protein, the first step recommended by Codex Alimentarius (2003) is to consider the source of the protein. Bacillus thuringiensis has been the source of numerous genes expressing various Cry proteins. Several of these proteins have been introduced into transgenic crops that have been consumed worldwide and none of them has been shown to elicit allergic reactions in humans or animals (Mendelsohn et al., 2003). Sequence analysis of Cry1Ia1 protein revealed no similarity to known allergens and because the Cry1Ia1 protein digests rapidly and does not show stability in simulated gastric fluid, it does not present an allergenicity concern. Furthermore, thermostability studies indicated that the Crylal protein is inactivated by heating to $100{ }^{\circ} \mathrm{C}$ for 3 to 4 min. With normal cooking methods for potatoes (boiling, deep frying, and baking), the $100{ }^{\circ} \mathrm{C}$ temperature is exceeded and the 
Table 4. Summary of food safety tests conducted on Escherichia coli-produced Cry1Ia1 protein or the potato cultivar SpuntaG2 expressing CrylIa1 protein.

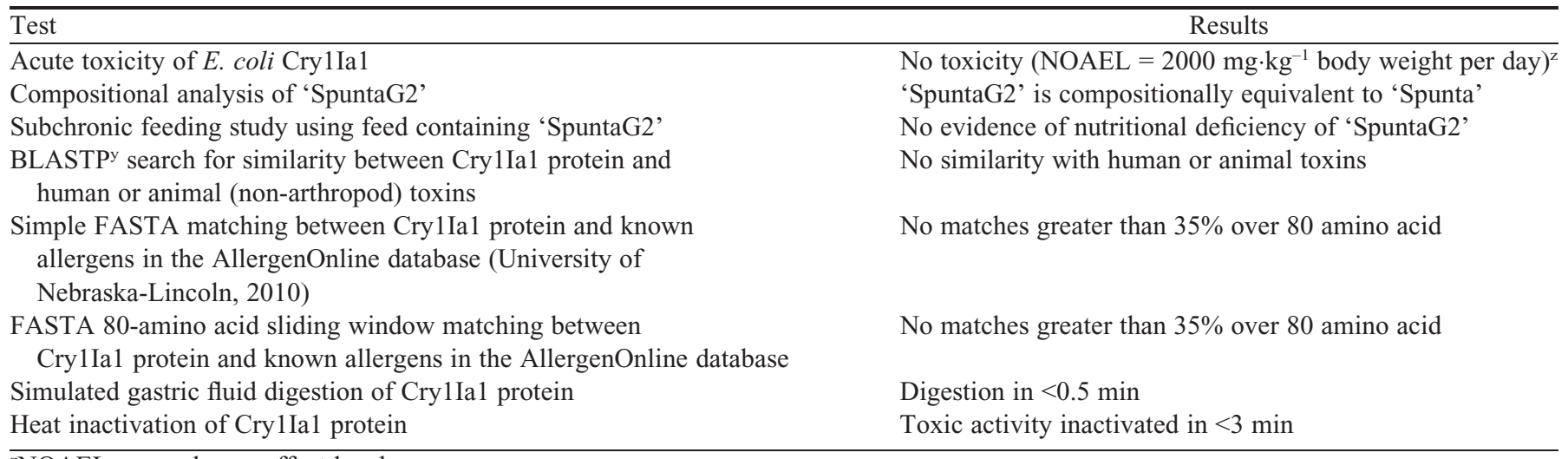

${ }^{2} \mathrm{NOAEL}=$ no adverse effect level.

${ }^{\text {yBLASTP }}=$ Basic Local Alignment Search Tool Protein.

time of exposure surpasses 3 to $4 \mathrm{~min}$. Therefore, during typical preparation of potatoes, the CrylIal protein is completely inactivated. From the standpoint of allergenicity, this means that the protein is degraded and, consequently, any allergy-inducing epitopes would be destroyed. This is additional evidence that the Cry1Ia1 protein poses no concern for allergenicity.

The nptII gene was included in the construct to transform 'SpuntaG2' for use as a selectable marker to identify transformed plants during tissue culture regeneration. Therefore, the safety of the NPTII protein must be addressed for 'SpuntaG2'. The food and feed safety of the enzyme, NPTII produced by the nptII gene, has been widely assessed. Lack of toxicity and allergenicity of NPTII as well as the lack of glycosylation of this protein in planta has already been demonstrated (Fuchs et al., 1993a, 1993b). Based on this body of evidence, the NPTII protein has been deemed safe and the npt II gene has been used in 70 approved transgenic events that include potato, maize (Zea mays), sugar beet (Beta vulgaris), canola (Brassica rapa), papaya (Carica papaya), chicory (Cichorium intybus), cotton (Gossypium hirsutum), flax/linseed (Linum usitatissimum), tomato (Solanum lycopersicum), tobacco (Nicotiana tabacum), and plum (Prunus domestica) (AGBIOS, 2010). Twenty of the approved events containing the nptII gene are in potato. Furthermore, the level of NPTII protein in 'SpuntaG2' leaves (as determined by ELISA) is consistent with those in other transgenic potato lines and the protein is equivalent to NPTII proteins in crops that have been deregulated.

The nutritional composition of 'SpuntaG2' was not significantly different from that of non-transgenic 'Spunta'. Because the compositional analysis showed equivalence between 'SpuntaG2' and 'Spunta', a feeding study would not normally be required. Furthermore, Codex Alimentarius (2003) cautions that feeding studies employing whole foods have limited value in safety assessment and must be conducted such that nutritional imbalances by feeding with abnormally high amounts of the test food are not caused. None-the-less, a rodent feeding study was conducted as an additional assurance of nutritional adequacy and absence of unintended effects. In these experiments, the control and experimental groups had no significant differences for the parameters tested, which is indicative of compositional equivalency.

In the third article of our three-article series, additional experiments were done to determine the efficacy of 'SpuntaG2' for controlling potato tuber moth infestation in the field and storage and to compare non-transgenic 'Spunta' and 'SpuntaG2' for agronomic, quality, and processing traits, as well as yield (Douches et al., 2010). The results of those experiments showed that 'SpuntaG2' gave complete resistance to potato tuber moth infestation in the field and in storage and that it did not differ from non-transgenic 'Spunta' with respect to yield, other important agronomic properties, tuber quality, and processing traits.

Taken as a whole, the results of this study strongly indicate that Cry1Ia1 protein, along with the NPTII protein and the plant expressing them, 'SpuntaG2', are not a human health risk. Therefore, using the 'SpuntaG2' potato, a safe alternative to chemical pesticide use, benefits not only the grower, but the consumer and the environment as well.

\section{Literature Cited}

AGBIOS. 2010. GM crop database. 1 Mar. 2010. <http://www.agbios. com/dbase.php>.

Altschul, S., T. Madden, A. Schäffer, J. Zhang, Z. Zhang, W. Miller, and D. Lipman. 1997. Gapped BLAST and PSI-BLAST: A new generation of protein database search programs. Nucleic Acids Res. 25:3389-3402.

Beck, E., G. Ludwig, E. Auerswald, B. Reiss, and H. Schaller. 1982. Nucleotide sequence and exact localization of the neomycin phosphotransferase gene from transposon Tn5. Genetics 19:327336.

Benford, D. 2000. The acceptable daily intake: A tool for ensuring food safety. International Life Sciences Institute, Washington, DC.

Codex Alimentarius. 2003. Guideline for the conduct of food safety assessment of foods derived from recombinant-DNA plants CAC/GL 45-2003. 1 Mar. 2010. <http://www.codexalimentarius.net/web/ index_en.jsp>.

Delaney, B., J. Astwood, H. Cunny, R. Conn, C. Herouet-Guicheney, S. MacIntosh, L. Meyer, L. Privalle, Y. Gao, J. Mattsson, and M. Levine. 2008. Evaluation of protein safety in the context of agricultural biotechnology. Food Chem. Toxicol. 46:S71-S97.

Douches, D., W. Li, K. Zarka, J. Coombs, W. Pett, E. Grafius, and T. El-Nasr. 2002. Development of Bt-cry5 insect resistant potato lines 'Spunta-G2' and 'Spunta-G3'. HortScience 37:1103-1107.

Douches, D., W. Pett, D. Visser, J. Coombs, K. Zarka, G. Bothma, J. Brink, K. Felcher, M. Koch, and H. Quemada. 2010. Field and storage evaluations of 'SpuntaG2' for resistance to potato tuber moth and agronomic performance. J. Amer. Soc. Hort. Sci. 135:333340 . 
European Food Safety Authority. 2007. Statement of the scientific panel on genetically modified organisms of the safe use of the nptII antibiotic resistance marker gene in genetically modified plants. 1 Mar. 2010. <http://www.efsa.europa.eu/EFSA/Statement/gmo_ statement_nptII_,0.pdf $>$.

$\mathrm{Fu}, \mathrm{T}$., U. Abbott, and C. Hatzos. 2002. Digestibility of food allergens and nonallergenic proteins in simulated gastric fluid and simulated intestinal fluid: A comparative study. J. Agr. Food Chem. 50:7154-7160.

Fuchs, R., J. Ream, B. Hammond, M. Naylor, R. Leimgruber, and S. Berberich. 1993b. Safety assessment of the neomycin phosphotransferase II (NPTII) protein. Nat. Biotechnol. 11:1543-1547.

Fuchs, R., M. Gustafson, G. Rogan, D. Bartnicki, R. Leimgruber, R. Finn, A. Hershmn, and S. Berberich. 1993a. Purification and characterization of microbially expressed neomycin phosphotransferase II (NPTII) protein and its equivalence to the plant expressed protein. Nat. Biotechnol. 11:1537-1542.

Gill, S., E. Cowles, and P. Pietrantonio. 1992. The mode of action of Bacillus thuringiensis endotoxins. Annu. Rev. Entomol. 37:615-636. International Conference on Harmonisation of Technical Requirements for Registration of Pharmaceuticals for Human Use. 1997. Preclinical safety evaluation of biotechnology-derived pharmaceuticals. ICH S6. 1 Mar. 2010. <http://www.ich.org/cache/compo/276254-1.html>.

Laemmli, U. 1970. Cleavage of structural proteins during the assembly of the head of bacteriophage T4. Nature 227:680-685.

Li, W., K. Zarka, D.S. Douches, J.J. Coombs, W.L. Pett, and E.J. Grafius. 1999. Co-expression of potato PVY coat protein gene and cryV-Bt genes in potato (Solanum tuberosum L.). J. Amer. Soc. Hort. Sci. 124:218-223.

Mendelsohn, M., J. Kough, V. Zigfridais, and K. Matthews. 2003. Are Bt crops safe? Nat. Biotechnol. 21:1003-1009.

MPI Research, Inc. 2008. Acute oral toxicity study of Cry1IA1 protein in mice. Study number 1466-001. MPI Research, Inc., Mattawan, MI. National Center for Biotechnology Information, U.S. National Library of Medicine. 2010. Basic local alignment search tool. Protein BLAST. 1 Mar. 2010. <http://blast.ncbi.nlm.nih.gov/Blast.cgi>.

Organization for Economic Co-operation and Development. 2002. Consensus document on compositional considerations for new cultivars of potatoes: Key food and feed nutrients, anti-nutrients and toxicants. 1 Mar. 2010. <http://www.olis.oecd.org/olis/2002doc.nsf/ LinkTo/env-jm-mono\%282002\%294>.

Pearson, W. 2000. Flexible sequence similarity searching with the FASTA3 program package. Methods Mol. Biol. 132:185-219.
Rice, E., T. Lee, G. Rogan, and G. Bannon. 2008. Safety assessment of proteins used in crops developed through agricultural biotechnology. Industry perspective, p. 237-258. In: B.C. Hammond (ed.). Food safety of proteins in agricultural biotechnology. CRC Press, Boca Raton, FL.

Rogan, G., J. Bookout, D. Duncan, R. Fuchs, P. Lavrik, S. Love, M. Mueth, T. Olson, E. Owens, P. Raymond, and J. Zalewski. 2000. Compositional analysis of tubers from insect and virus resistant potato plants. J. Agr. Food Chem. 48:5936-5945.

South African Medical Research Council. 2002. Report on South African food consumption studies undertaken amongst different population groups (1983-2000): Average intakes of foods most commonly consumed. Table 44: Summary of food items commonly consumed by children and adults in South Africa. 5 Apr. 2010. $<$ http://www.mrc.ac.za/chronic/foodstudy.pdf $>$.

Stone, T. and P. Lavrik. 1994. Petition for determination of nonregulated status. Potatoes expressing the colorado potato beetle control protein of Bacillus thuringiensis subsp. tenebrionis. USDA/ Aphis Petition 94-257-01. 1 Mar. 2010. <http://www.aphis.usda.gov/ brs/aphisdocs/94_25701p.pdf>.

U.S. Food and Drug Administration. 1994. Secondary food additives permitted in food for human consumption: Food additives permitted in feed and drinking water of animals; aminoglycoside 3' -phosphotransferaseII. Final rule. Fed. Regist. 59:26700-26711.

U.S. Food and Drug Administration. 2004. Toxicological principles for the safety assessment of food ingredients. Redbook 2000. 5 Apr. 2010. <http://www.fda.gov/Food/GuidanceComplianceRegulatory Information/GuidanceDocuments/FoodIngredientsandPackaging/ Redbook/default.htm>.

U.S. Food and Drug Administration. 2008. Good laboratory practices for nonclinical laboratory studies. Title 21, code of federal regulations part 58. U.S. Food and Drug Administration, Washington, DC. University of Nebraska-Lincoln. 2010. AllergenOnline. 1 Mar. 2010. $<\mathrm{http}$ ://www.allergenonline.com>.

Wilson, C., J. Kreychman, and M. Gerstein. 2000. Assessing annotation transfer for genomics: Quantifying the relations between protein sequence, structure and function through traditional and probabilistic scores. J. Mol. Biol. 297:233-249.

Zarka, K., R. Greyling, I. Gazendam, D. Olefse, K. Felcher, G. Bothma, J. Brink, H. Quemada, and D.S. Douches. 2010. Insertion and characterization of the crylIal gene in the potato cultivar Spunta for resistance to potato tuber moth. J. Amer. Soc. Hort. Sci. 135:317324. 